\title{
The Influence of Trust and Risk on Intention to Use E-Democracy in Nigeria
}

\section{Charles K. Ayo}

Covenant University, Ota, Nigeria; charles.ayo@covenantuniversity.edu.ng

Victor W. Mbarika

Southern University and A\&M College, USA; victor@mbarika.com

Aderonke A. Oni

Covenant University, Ota, Nigeria; ronke.oni@covenantuniversity.edu.ng

Doi:10.5901/mjss.2015.v6n6s1p477

\section{Abstract}

\begin{abstract}
Studies revealed that the level of success and diffusion of e-democracy is low in the developing nation as opposed to the developed nations where it has reached active participation stage. To investigate users' acceptance of e-democracy from developing nation's perspective, this study employed an extended technology acceptance model (TAM) which integrates trust, perceived risk and task-technology fit. The results supported the hypothesized positive relationship between perceived usefulness and intention to use e-democracy. However, contrary to TAM perceived ease of use shows no significant effect on intention to use e-democracy. Finding also revealed that lack of trust in government and in the democratic process is a limiting factor to citizens' e-democracy acceptance.
\end{abstract}

Keywords: e-Democracy, Political Participation, Trust, Perceived Risk, TAM, ICT

\section{Introduction}

Information and Communication Technology (ICT) has been convincingly argued to be a catalyst for development in developing countries. It has the potential to transform dysfunctional public administration and to provide unprecedented opportunities for the information-intensive social services (Sahay and Avgerou, 2002; LeBlanc, Mbarika, McCoy and Meso, 2004). Most countries have leveraged on ICT tools to foster new relationships between citizens and the State in order to alleviate the crisis of democratic legitimacy, develop and deliver high quality public services; facilitate successful constituent relationship management; and support the economic and social development goals of citizens, business, and civil society at local, state, national and international levels (Grant and Chau, 2006; Lai and Pires, 2010).

E-democracy is a form of democratic practice that can complement the traditional mode of interaction between parliaments, local authorities, government executive, and citizens (Coleman and Gotze, 2001). E-democracy has the potential to destroy the distrust that exists between the government and the people especially in African countries. By disseminating information online and seeking public opinion on policy issues through online consultation and deliberation, government can become transparent, accountable and regain trust and confidence of the people they govern. In view of the attempt of governments across African nations to begin online interaction with citizens, this study explores factors that influence citizens' acceptance of e-democracy. According to Carter and Belanger (2005), citizens' acceptance of government electronic related services is not only a technological concern but largely affected by social, human and cultural factors. The study reviews existing literature on technology adoption and developed a research model based on Technology Acceptance Model (TAM) extended with perceived risk and trust to evaluate citizens' intention to use online political participation system.

The rest of the paper is organized as follows; section two presents an overview of e-democracy and its practices in developing countries. Sections three presents the background theory, research model and hypotheses. Research methodology, data collection and research instrument are discussed in section four. Section five presents the data analysis and result and section six presents the discussion of findings, conclusion and further research. 


\section{Overview of e-Democracy}

One special type of Government-to-citizen electronic interaction is when elected representatives and political parties interact online with the citizens nationally or in their constituencies. This is commonly referred to as e-democracy (Palvia and Sharma, 2007). E-Democracy is considered the application of modern communication technologies to democratic governance. According to Cliff (2000), e-Democracy is the use of information and communication technologies and strategies by democratic actors (governments, elected officials, the media, political organizations, citizens/voters) within political and governance processes of local communities, nations and on the international stage. The essence of edemocracy is to provide wider access for dissemination of information and promotes communication and deliberation among the democratic actors. E-democracy is a technology-based mechanism enabling people to effectively participate in the decision-making processes that affect their lives, society and put checks and balances on government activities and behaviors (Palvia and Sharma, 2007).

E-democracy is divided into two distinct areas: e-participation and e-voting (Macintosh, 2004). E-participation includes political or current affairs discussion and online consultation between representatives and their constituents (Palvia and Sharma, 2007). E-democracy is based on the democratic principle of an informed and engaged citizenry. Among the important issues in e-democracy development is the acquisition an e-democracy system that considerably meets the needs of the citizens to participate in the democratic process and the government's needs to provide citizens with adequate participation channels (Funikul and Chutimaskul, 2009). More importance to this is the acceptance of citizens to use the e-democracy platform. According to Carter and Belangers (2005), citizens' adoption of e-government services is not only about availability of technology but influence by social, economic and cultural factors.

Like the developed countries, African countries are also giving their legislative bodies online presence, using the Internet to provide information on legislatures activities to the citizens and receiving feedback through mechanisms such as online survey and opinion poll. Although, e-democracy practices in African started with private initiatives such as Katabuna.net, naijavoice.com, nairaland.com, nigeriavillagesquare.com, 234next.com, vaugaronline.com and Ushahidi, governments are now catching up with the global trend. The Burkina Faso's national portal is the first African portal which allows for online consultation (UN e-government Survey, 2008).

Others are coming to terms with the use of ICT in interacting with their citizens. Nigerian government, towards the end of the year 2012, launched the "constitutionreview.org" with the aim of giving more citizens aside the elite, the opportunity to take part in the constitution review process. Nigeria through her nigeria.gov.ng, also implemented feedback form which can be directed to specific government official (www.nigeria.gov.ng/). The South African official website (www.gov.za) also makes available documents for download and comments. The Ghanaian official Web site (www.ghana.gov.gh), allows citizens to participate in opinion poll.

However, citizens' intention to use the available e-democracy platforms is yet to be explored. There is not much literature on factors that influence citizens' intention to use the e-democracy especially in developing nations.

\subsection{Review of Related Theories}

Previous research works have investigated user's adoption of technologies using theories such as Technology Acceptance Model (TAM), Theory of Reasoned Action (TRA), Diffusion of Innovation (DOI), Theory of Planned behaviour, Unified Theory of for Acceptance and Use of Technology (UTAUT), Task Technology Fit (TTF), Technology Organisation Environment (TOE) (Davis, 1989; Rogers, 1995; Goodhue and Thomson, 1995; Fishbein and Ajzen, 1975; Venkatesh et al., 2003)

\subsubsection{TAM}

The Technology Acceptance Theory (TAM) proposes that user's acceptance of new technologies can be predicted based on his perception of the system. TAM was developed by Davis (1989) based on the Theory of Reasoned Action (TRA) proposed by Fishbein and Ajzen (1975). The constructs in TAM include Perceived Usefulness (PU), which refers to the user's perception of the expected benefits derived from the use of the technology; and Perceived Ease of Use (PEOU), which refers to the degree to which a user believes that the use of a particular technology would be free of effort. According to TAM, PU and PEOU are determinants of user's attitude towards usage intention. Perceived usefulness and perceived ease of use have been used extensively in examining users' acceptance of information system both in eBanking (Adesina et al., 2008; Ayo et al., 2012), e-Commerce (Lee et al., 2001; Chen et al., 2002; Ayo et al., 2011), and e-Government/e-democracy/e-Participation (Carter and Belanger, 2005; Alomari et al., 2010). Technology that is 
perceived as easy to use and useful in accomplishing a given task will have a positive influence on user's intention to use the technology.

TAM has also been extended to include other constructs such as self-efficacy, trust amongst others (Wang et al., 2003; Ifinedo, 2007; Hanudin 2007; Adesina et al., 2008; Ayo et al. 2011; and Ayo et al., 2012). Alomari et al (2010) found perceived usefulness as one of the social factors affecting e-Government adoption.

Building on these proven views, TAM is suitable for evaluating e-democracy usage but TAM may not sufficiently measure the user's intention to adopt e-democracy. This study therefore, proposes an extended TAM which integrates trust, perceived risk and task-technology fit to better predict citizens' adoption of e-democracy.

\subsubsection{Trust and TAM}

Trust, security, and privacy attract more attention in Web-based application. Pavlou (2003) described trust as the "belief that the other party will behave in a socially responsible manner, and, by so doing, will fulfil the trusting party's expectations without taking advantage of its vulnerabilities". The major concern of Web-based systems users around the world is the fear that their information could be misused (Layne and lee, 2001; Adesina et al., 2008; Alomari et al., 2010). Carter \& Belanger (2005) emphasized that citizen's perceptions of trustworthiness issues such as security and privacy (trust of Internet and of government) also influence the use of e-Government services. They proposed a model of trust in e-Government as comprising of trust in the Internet (TOI), trust in government (TOG) and perceived risk. While eGovernment services require citizens to exchange personal data such as credit card, e-democracy on the other hand could require citizens to supply their personal contacts. Trust in e-democracy also include trust in Internet technology and trust in government to keep their promises; protect citizen's data, not use their opinion against them, and sincerely consider their opinions in decision making.

Lopez-Sisniega (2009), tested constructs from TAM, DOI and web trust to investigate barriers to electronic government adoption among taxpayers in Chihuahua, Mexico.

\subsubsection{Perceived Risk and TAM}

Risk is the state of being Vulnerable to loss or injury (Bernard 1989, p.894). Perceived risk is the subjective probability that loss or injury will occur (Ayo, Adewoye and Oni, 2011). In the context of e-democracy, citizens are likely to perceive risks when they are uncertain about the probability of outcome of releasing their personal data or expressing their opinion.

TAM's propositions centre on the positive aspects of technology use i.e. usefulness and ease of use and little or no consideration for the immediate loss that could result from usage (Ayo, Adewoye and Oni, 2011). This narrowed the argumentative power of TAM in situations where there is potential loss due to usage. Several e-Commerce researchers (Ayo, Adewoye and Oni, 2011; Li et al., 2009; Belkhamza et al., 2009) had used perceived risk to increase the explanatory power of TAM in examining consumers' behavior.

The perceived risk was found to have negative influence on intention to adopt information system (Pavlou, 2003). Several research have investigated e-government services/e-democracy using TAM constructs, DIO constructs, perceived behavioural control (PBC), subjective norm (SN) trust, UTAUT (Al-Hujran et al., 2014; Kollmann and Kayser, 2010; Carter and Bélanger, 2005; Azmi and Bee). Perceived risk has been rarely considered in e-government and related services. Kumar et al. (2007) in a concept investigation of e-government services in Canada identified perceived risks in terms of financial and performance risk, data security and privacy as component of user characteristics that influence egovernment adoption but the model is yet to be tested empirically.

Online political participation systems often require users to submit some personal information such as name and contact address. Coupled with the fact that e-democracy is a new phenomenon it is important to investigate impact of perceived risk that may be associated with expressing ones opinion and given personal details on its adoption.

\subsubsection{TTF and TAM}

Task-technology fit (TTF) theory developed by Goodhue and Thompson (1995) proposed that information technology (IT) is more likely to positively influence individual performance and it would be used if the capabilities of IT match the tasks that the user have to perform. Both TTF and TAM offers similar perspectives on utilization behavior. While TAM focuses on attitude towards using a particular information system (IS) based on PU and PEOU, TTF focuses on matching users task needs and the IS functionalities (Ayo et al., 2011). TTF according to Goodhue and Thompson (1195) is the degree to 
which a technology assists an individual in performing his/her task. The centre of task-technology fit theory is tasktechnology fit construct (TTF) which is the ability of technology to aid accomplishment of the task. TTF construct essentially matches the potential of technology the requirements of the task. Relating e-democracy, TTF can be referred to as the degree to which technology aids an individual political participation. Dishawa and Strong (1999) argued that combining TTF and TAM into one extended model better explain technology adoption than either of the models alone. TTF has been used in prior research to predict individual adoption of information system in e-commerce and e-tourism (Klopping et al., 2004; Sun et al., 2007; Usoro, 2010). According to Goodhue and Thompson (1995) and Laurn and Huang (2009), this research considers TTF construct of TTF model as antecedent to PU, PEOU, and IU

Azmi and Bee (2010), investigated the adoption of e-filling system by taxpayers in Malaysia using TAM. Carter and Belangers (2005) investigated factors influencing individual's intention to use an electronic government service. They proposed a model incorporating perception constructs from TAM, DOI, and Web trust to investigate citizens' adoption of e-government services. The constructs incorporated into the model include: Perceived Ease of Use (PEOU), Perceived Usefulness (PU), Compatibility, Relative Advantage, Image, Trust of Internet and Trust of government institution. The model was tested on e-government services offered on State of Virginia e-government platform and their analysis found support for significant effects of perceived trustworthiness (composed of both internet trust and trust in government), perceived ease of use, and compatibility on a person's intention to use an e-government service. Hussein, Mohamed, Ahlan, Mahmud, and Aditiawarman (2010) examined consumer electronic government adoption in Malaysia using a model that incorporated perception constructs from TAM, DOI, trustworthiness, perceived risk and self-efficacy.

\subsubsection{Research Model and Hypotheses}

Based on the proposition of TTF to match user's task needs and IT functionalities, we therefore put forward the following hypotheses:

H1: Task-technology fit has a positive effect on perceived usefulness of e-democracy.

H2: Task-technology fit has a positive effect on perceived ease of use of e-democracy.

H3: Task-technology fit has positive effect on intention to use e-democracy.

According to Davis (1989), it is expected that perceived usefulness and perceived ease of use will influence intention to use e-democracy Web sites. Kamel and Hassan (2003), Al-Sukkar and Hasan (2005) and Vatanasombut et al. (2008) Ayo et al. (2011) found perceived usefulness and perceived ease of use as positive antecedent of intention to use. Therefore, the following hypotheses are proposed:

H4: Perceived usefulness has a positive effect on intention to use e-democracy Web sites.

H5: Perceived ease of use has as positive effect on intention to use e-democracy Web sites.

In e-commerce, perceived risk has been widely used as predictor measure of perceived usefulness and perceived ease of use before purchasing products or services (Jarvenpaa et al., 2000). Several other research works also validated the negative influence of perceived risk on perceived usefulness and perceived ease of use (Kollmann and Kayser, 2010). To further prior studies, this study examines the effect of perceived risk on perceived usefulness and its direct effect on intention to use e-democracy Web sites. We therefore proposed the following hypotheses:

H6: Perceived risk negatively influences perceived usefulness of e-democracy.

$\mathrm{H7}$ : Perceived risk negatively influences intention to use e-democracy.

According to Stewart (1999) the channel and the target firm are the two objects to be trusted in Internet transactions. In e-democracy the two objects of trust are the government and the e-channels. Trust in government could be trustworthiness of the people in authority to keep electoral promises and to protect the interest of the citizens. Trust in e-democracy could also include the lack of perception of risk in releasing personal information and the belief of freedom of expression. Based on these identified trust issues, it is therefore hypothesized that:

H8: Perceived risk has a negative influence on trust in e-democracy.

H9: Citizens' trust in government positively influences intention to use e-democracy. 


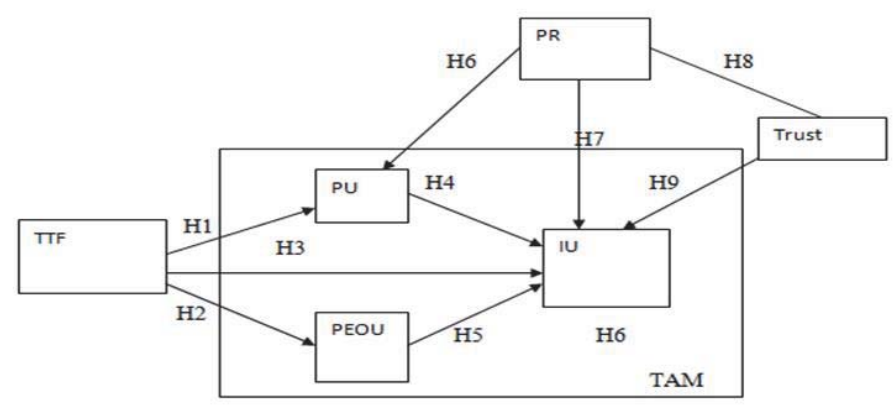

Figure 1: Research Model and Hypotheses

\subsubsection{Research Methodology}

The survey research method was used in this study because it provides basis for generalisation. Questionnaire was designed and administered to evaluate factors that influence citizens' intention to use e-democracy portals in some selected countries in Africa. The questionnaire was administered online using Google Form. Electronic method was used in order to get individuals who are educated, Web users and likely users of e-democracy platforms. Research in Jordan found that educated people are early adopters of the Internet and potential users of e-democracy services (Al-Jaghoub and Westrup, 2003). E-mail message containing the link to the Google Form, and the essence of the survey was sent to the respondents. The population included every individual on the investigators' mailing lists (40) and the mailing lists of every individual so listed on the list. It presents a form of viral marketing, whereby we are able to reach as many people as possible electronically. It was also a strategy target A total 287 responses were received and 21 were rendered invalid due to multiple skipped questions in the part that relates with the research model. A total number of 266 valid responses were used to test the research model and hypotheses based on Partial Least Square Structural Equation Modelling (PLSSEM) approach. SmartPLS 2.0 was used as the data analysis tool. As opposed to regression-based methods, which analyse only one layer of relationship between independent and dependent variables at a time, SEM allows simultaneous modelling of relationships among multiple independent and dependent constructs (Urbach and Ahlemann, 2010). With SEM, one no longer distinguishes between dependent and independent variable but between the exogenous and endogenous latent variables (Haenlein and Kaplan, 2004).

\subsubsection{Research Instrument}

The questionnaire was divided into three sections. The first section consists of demographic profile of respondents. The second section deals with the level of technology usage by respondents, while the third section focuses on measures of model construct, including perceived ease of use, perceived usefulness, behavioral intention, trust, perceived risk and task-technology fit. The third section consists of 18 questions; 3 questions on perceived risk, 3 questions on tasktechnology fit, 3 questions on perceived ease of use, 3 questions on perceived usefulness, 3 questions on attitude, and 3 questions on intention to use. The scales for measuring perceived usefulness, perceived ease of use, intention to use, actual use, and task-technology fit were adapted from Davis et al. (1989), Klopping and McKinney (2004), and Goodhue et al. (1995). These prior studies have established the reliability and validity of the scales. Measures of scale for trust dimension were adapted from Tzy-wen et al. (2005) and Pavlou (2003). Perceived risk measurement scale was adapted from Pavlou (2003) and Belkhamza et al. (2009). All the model constructs were measured on five-point Likert scale ranging from 1 = "strongly disagree," 2 = "disagree," 3 = "neutral," 4 = "agree," to 5 = "strongly agree".

\section{Data Analysis and Discussions}

\subsection{Demographic profile}

Frequency distribution of the demographic analysis of the respondents showed that $74.4 \%$ of the respondents were male and $25.6 \%$ were female. There were more respondents from Nigeria than all the other countries. $48.1 \%$ of the 
respondents were from Nigeria, $21.8 \%$ from South Africa, 17.3\% from Ghana and $12.7 \%$ from Cameroon. $85.7 \%$ of the respondents fell within age 20 - 50 years. $42.1 \%$ and $32.3 \%$ of the respondent were educationist and IT and Telecommunication personnel respectively. In terms of education, $30.8 \%$ of the respondent had first degree and $65.4 \%$ had above B.Sc.

\subsection{Technology Usage of Respondents}

Assessment of the technology usage of the respondent showed that almost all the respondents were Internet and mobile phone users. $91.0 \%$ of the respondents confirmed that they use Internet at home, $96.2 \%$ use Internet at work and only $22.6 \%$ indicated using Internet at Cyber cafe. $98.5 \%$ of the respondents have mobile phone, $67.7 \%$ usually access the Internet on their mobile phone, $14.3 \%$ occasionally used their mobile phone to access the Internet and only $18.0 \%$ do not access the Internet on their mobile phone at all.

Further examination of the technology usage of respondents showed that $84.2 \%$ of the respondents were active in interacting with peers through social media. $10.5 \%$ occasionally interact with peers through social media. About half (56.4\%) of the respondent indicated that their countries have Web sites for all government ministries and agencies, $16.5 \%$ indicated that not all government ministries and agencies have Web site. $27.1 \%$ responded that not all government ministries and agencies have Web sites.

On government's online interaction with citizens through official Web sites, 20.3\% indicated active government interaction with citizens via Web sites, $43.6 \%$ indicated occasional government interaction with citizens via Web sites and $23.3 \%$ indicated no online interaction at all. $26.3 \%$ of the respondents indicated that their government use Social media to interact with citizens, $38.3 \%$ indicated that their government is not involved in the use of social media interaction with citizens, while $35.3 \%$ indicated occasional use of social media to interact with citizens. On online polling usage, about half (54.1\%) of the respondents indicated that their government does not use online polling to get opinions of the citizens, $28.6 \%$ indicated occasional use on online polling and $17.3 \%$ indicated frequent use of online polling.

\subsection{Validity and Reliability of the Research Instrument}

The convergence validity of the research instrument was evaluated using confirmatory factor analysis while the discriminant validity was evaluated using cross-loading assessment and comparison of average variance extracted (AVE) square root and the $\varphi$ matrix. Table 2, shows the factor-analysis loadings of each item on its respective latent variable. For an item to be retained for further analysis after the initial run, it should have standardised loading not less than 0.707 on its respective latent construct (Chin, 1998). All the items in the research instrument satisfied this condition and are retained for further analysis.

Table 2: Confirmatory Factor Analysis

\begin{tabular}{|l|c|c|}
\hline Confirmatory Factor Analysis & Items & Loading \\
\hline Construct & IU1 & 0.914 \\
\hline \multirow{3}{*}{ Intention to Use } & IU2 & 0.871 \\
\cline { 2 - 3 } & IU3 & 0.825 \\
\hline \multirow{3}{*}{ Perceived Ease of Use } & PEOU1 & 0.878 \\
\cline { 2 - 3 } & PEOU2 & 0.904 \\
\cline { 2 - 3 } & PEOU3 & 0.917 \\
\hline \multirow{3}{*}{ Perceived Risk } & PR1 & 0.698 \\
\cline { 2 - 3 } & PR2 & 0.872 \\
\cline { 2 - 3 } Perceived Usefulness & PR3 & 0.901 \\
\hline \multirow{3}{*}{ Technology Task Fit } & PU1 & 0.849 \\
\cline { 2 - 3 } & PU2 & 0.906 \\
\cline { 2 - 3 } & PU3 & 0.823 \\
\hline \multirow{3}{*}{ rrust } & TTF1 & 0.899 \\
\cline { 2 - 3 } & TTF2 & 0.944 \\
\cline { 2 - 3 } & TTF3 & 0.85 \\
\cline { 2 - 3 } & Trust1 & 0.9 \\
\cline { 2 - 3 } & Trust2 & 0.913 \\
\cline { 2 - 3 } & Trust3 & 0.943 \\
\hline
\end{tabular}


The cross loading of the item showed that no item loaded more on any construct other than its theoretically assigned construct. This showed that all the items loaded uniquely on their respective theoretical construct.

The second step in establishing discriminant validity is the AVE analysis. The square root of the AVE of each construct was compared with the correlation score of each pair of latent variables. Table 3 displays the AVE square root and the $\varphi$ matrix of the entire latent construct. In no case was any $\varphi$ matrix greater that the square root of AVE of any construct in our model.

Table 3: Reliability and Discriminant Validity Statistics of Research Instrument

\begin{tabular}{|c|c|c|c|c|c|c|c|c|c|}
\hline Construct & Composite Reliability & Cronbach Alpha & AVE & IU & PEOU & PR & PU & TTF & Trust \\
\hline IU & 0.9056 & 0.8537 & $\mathbf{0 . 7 5 9}$ & $\mathbf{0 . 8 7 1}$ & & & & & \\
\hline PEOU & 0.9272 & 0.8827 & $\mathbf{0 . 8 0 9}$ & -0.001 & $\mathbf{0 . 8 9 9}$ & & & & \\
\hline PR & 0.8665 & 0.7722 & $\mathbf{0 . 6 8 6}$ & 0.306 & 0.098 & $\mathbf{0 . 8 2 8}$ & & & \\
\hline PU & 0.8961 & 0.8256 & $\mathbf{0 . 7 4 2}$ & 0.469 & -0.051 & 0.090 & $\mathbf{0 . 8 6 1}$ & & \\
\hline TTF & 0.9266 & 0.8815 & $\mathbf{0 . 8 0 8}$ & 0.156 & 0.257 & -0.010 & 0.209 & $\mathbf{0 . 8 9 9}$ & \\
\hline Trust & 0.9424 & 0.9081 & $\mathbf{0 . 8 4 5}$ & 0.040 & 0.363 & -0.255 & 0.078 & 0.457 & $\mathbf{0 . 9 1 9}$ \\
\hline
\end{tabular}

According to Pallant (2004) reliability is an assessment of the degree of consistency between multiple measurements of a variable. The internal consistency reliability and construct reliability of the research instrument was evaluated using cronbach alpha coefficient (a) and composite reliability $\left(r_{c}\right)$ respectively. According to Pallant (2004), Cronbach's alpha greater than 0.70 is acceptable. The minimum $r_{c}$ recommended for PLS is 0.8. Using SmartPLS 2.0, each of the constructs had cronbach alpha value above the standard guideline of 0.70 ; therefore, the instrument is reliable.

Table 3 also displayed the $r_{c}$ of the constructs, the Cronbach alpha and the AVE. All the constructs hypothesized in the research model have acceptable value for AVE, Cronbach alpha and composite reliability.

\subsection{Hypothesis Testing}

A multivariate analytical methodology for empirically examining sets of relationships in the form of linear causal models (Duncan, 1986) known as path analysis was used to test the research hypothesis. To test the nine (9) hypotheses proposed for this research, path analysis was used to evaluate the power of explanatory variables along each separate path. This approach is consistent with the methodology adopted by earlier similar research works (Klopping et al., 2004; Lee et al., 2001; Dishaw and Strong, 1999; Ayo et al., 2011).

The overall model fit shows that the entire model constructs $\left(R^{2}=0.248\right.$, Adjusted $R^{2}=0.234, t=17.158$, Pvalue $=$ 0.000 ) has significant effect on intention to use e-democracy system. However, not all the constructs in the model significantly influence intention to use e-democracy based on the individual path analysis. For the hypothesized relationship between PEOU to IU, the path coefficient of $(b=0.008, p>0.10)$ indicates that PEOU has no significant effect on behavioral intentions to use e-democracy systems. The path coefficient $(b=0.038, p>0.10)$ of the hypothesized relationship between trust to IU also indicates that trust has no significant effect on intention to use e-democracy.

The path coefficient of TTF to IU (H3) is significant at 0.05 and the path coefficient of PU to IU (H4), TTF to PEOU $(\mathrm{H} 2)$ and TTF to PU (H1) are significant at 0.01 significant levels. The path coefficient of PEOU to IU (H5) is significant at 0.01 significant levels. The path PR to PU $(b=0.085, p=0.166)$ is not significant at $0.01 \mathrm{SL}$. The path coefficient of PR to $\mathrm{IU}(\mathrm{H} 7, b=0248, p=0.000)$, is significant but not negative as hypothesized. The path coefficient of trust to PR ( $b=-0.210$, $p=0.000$ ) indicates that perceived risk has negative influence on trust and trust itself has significant effect on intention to use e-democracy. The summary of the path coefficients and hypotheses testing is given in table 3 .

Table 4: Path Coefficient and Hypotheses Testing

\begin{tabular}{|c|c|c|c|c|}
\hline Hypothesis & Relationships & Coefficient & p-value & Supported \\
\hline H1 & TTF - PU & 0.220 & 0.000 & Yes \\
\hline H2 & TTF- PEOU & 0.229 & 0.000 & Yes \\
\hline H3 & TTF-IU & 0.133 & 0.011 & Yes \\
\hline H4 & PU - IU & 0.345 & 0.000 & Yes \\
\hline H5 & PEOU - IU & 0.008 & 0.889 & No \\
\hline H6 & PR - PU & 0.085 & 0.166 & No \\
\hline H7 & PR - IU & 0.248 & 0.000 & No \\
\hline H8 & PR- Trust & -0.292 & 0.000 & Yes \\
\hline H9 & Trust - IU & 0.038 & 0.383 & Yes \\
\hline
\end{tabular}




\section{Discussion and Conclusion}

This paper evaluates citizens' intention to use e-democracy portals in Africa. An extended TAM model was developed to investigate citizens' intention to use e-democracy. The model evaluated perceived usefulness, perceived ease of use, perceived risk, trust, and task technology fit as antecedent to behavioral intention to use e-democracy. Questionnaires were designed and administered online to respondents to test the model. The result showed that there is a significant relationship between the model's constructs.

The results confirmed positive relationship between perceived usefulness and intention to use as proposed by Davis (1989). On the contrary to TAM, perceived ease of use shows no significant effect on intention to use. This disparity could probably be due to different domain of investigation or the fact that most of the respondents are computer literate, possess high level of education and are very familiar with the use of online social media.

As confirmed by previous research works (Ayo et al., 2011; Klopping and McKinney, 2004), extending TAM with TTF also fit the data. This study further confirm the significant relationship between task-technology fit, perceived usefulness, perceived ease of use and intention. This supports the findings of Klopping et al. (2004) and Ayo et al. (2011) that perceptions of usefulness of an information system are more dependent on technology fit to the task at hand.

The negative influence of perceived risk on trust proposed is supported and significant while the effect of trust on intention to use is not significant. This result statistically showed that risk is a predictor of trust. Risk significantly influences trust while trust has no significant effect on behavioral intention. This implies that people's trust in the democratic system will influence their participation in e-democracy. This finding is consistent with the research findings of Bélanger \& Carter (2008) and Lopez-Sisniega (2009). Detlor, Hupfer, Ruhi and Zhao (2009) investigation of the use of community municipal portal in Ontario also found that there is a greater level of trust in the government than the Internet. Drawing from these empirical findings, it can thus be said that citizens will be motivated to engage in online political participation when they believe in their government.

To advance on previous works, this study examines the direct impact of perceived risk on intention to use edemocracy and hypothesized that risk has a negative effect on intention to use. This hypothesis was not supported by the data as found in previous research (Bélanger \& Carter, 2008). This means that the respondents have no fear of disclosing their identity or expressing their opinion. This implies that it is not citizens' fear of disclosing their identity or expressing their opinion that will limit e-democracy in developing nations but the lack of trust in the people in government and in the democratic process.

Findings also showed that citizens will engage in e-democracy because they believe it is useful and it fits their needs for participating political. However, lack of trust in government to fulfil their electoral promises and maintain open and accountable democratic process may limit citizens' e-democracy adoption

Elected representatives should be encouraged to go online more to interact with their constituencies. Doing so especially at grassroots level will boost e-democracy implementation, make more citizens to be part of the political process and promote national development. Mizrahi and Vigoda-Godat (2009) asserted that participation in public decision making will yield positive result when there are channels to influence policy outcomes and democratic participatory behavior. Government should build citizens' trust in the political system by being more open, accountable and keeping electoral promises. These can be achieved through more information dissemination and early consultation and integration of citizens' opinion in decision making.

The findings of this research were dependent on the medium used for administering the questionnaire. The research was conducted in the US and online survey used to administer the questionnaire, thus, the bulk of the middle class and rural dwellers could not be reached. To further confirm these findings, questionnaires would be re-administered manually to this class of individuals upon return to Nigeria. Also the research model can be extended to include constructs from political science domain to assess the impact of non-technological factors on e-democracy adoption.

\section{Acknowledgements}

I wish to appreciate the Fulbright administration for the privilege given to me as an awardee of this prestigious fellowship that brought me to the US as a Fulbright African Research Scholar. Also, my host institution, the International Centre for Information Technology and Development (ICITD) at Southern University, Baton Rouge, Louisiana, and in particular the Director of the Centre, for making available to me all the resources required for my research work. Furthermore, I wish to acknowledge the support from my home institution for releasing for this fellowship and granting me all the privileges required. 


\section{References}

Adesina, A. A., Ayo, C.K. (2010). "An Empirical Investigation of the Level of Users' Acceptance of E-Banking in Nigeria". Journal of Internet Banking and Commerce, vol. 15, no.1 (http://www.arraydev.com/commerce/jibc/).

Alomari, M.K., Sandhu, K., Woods, P. (2010), "Measuring Social Factors in E-government Adoption in the Hashemite Kingdom of Jordan". International Journal of Digital Society (IJDS), Volume 1, Issue 2, June 2010.

Al-Jaghoub, S. and Westrup, C. (2003). Jordan and ICT-led Development: Towards a Competition State? . Information Technology \& People. 16(1): pp. 93-110.

Ayo, C. K, Adewoye J. O, and Oni A. A. (2010). "The State of e-Banking Implementation in Nigeria: A Post-Consolidation Review." Journal of Emerging Trends in Economics and Management Sciences (JETEMS) 1 (1): 37-45.

Ayo, C. K, Adewoye J. O, and Oni A. A. (2011). "Business-to-Consumer (B2C) e-commerce Implementation in Nigeria: The Prospect and Challenges." African Journal of Business Management, Vol. 5(13), pp. 5109-5117, 4 July, 2011,

Ayo, C.K. (2009): "Information Systems and Technologies", MCKAY Educational Series, Lagos, ISBN 978-978-900-565-9, 649p.

Ayo, C.K., Ifinedo, P., Ekong, U.O. and Oni, A. (2012) "An Empirical Evaluation of the Effects of Gender Differences and self-Efficacy on e-Banking Adoption in Nigeria: A modified Technology Adoption Model", In Abel Usoro, Grzegorz Majewski, Princely Ifinedo and Iwara I Arikpo (Eds), Leveraging Developing Economies with the Use of Information Technology: Trends and Tools, IGI Global.

Bélanger, F., \& Carter, L. (2008). "Trust and risk in e-government adoption". The Journal of Strategic Information Systems, 17(2), 165176. doi: DOI: 10.1016/j.jsis.2007.12.002.

Belkhamza Z, Wafa SA (2009). "The Effect of Perceived Risk on the Intention to Use E-commerce: The Case of Algeria". Journal of Internet Banking and Commerce, Volume 14, Issue 1.

Baum, C. and Di Maio, A. (2000). Gartners four phases of e-government model. http://www.gartner.com/DisplayDocument?id=317292.

Caldow Janet (2004): e-Democracy: Putting down global roots, Institute for Electronic Government, IBM.

Carter, L., and Bélanger, F. (2005). The Utilization of E-Government Services: Citizen Trust, Innovation, and Acceptance Factors. Information Systems Journal 15(1): 5-25.

Chen L, Gillenson M, Sherrell D (2002). Enticing online consumers: An extended technology acceptance perspective. Inform. Manag., 39(8): 705-719.

Coleman, S. and Gotze, J. (2001), "Bowling Together: Online Public Engagement in Policy Deliberation". Hansard Society. Retrieved $8^{\text {th }}$ Oct., 2010 [www.hansardsociety.org.uk]

Davis, F. D. (1989). Perceived usefulness, perceived ease of use, and user acceptance of information technology, MIS Quarterly, Vol. 13, No. 3, pp. 318-39.

Detlor, B., Hupfer M. E., Ruhi U. and Zhao L. (2013), "Information quality and community municipal portal use". Government Information Quarterly, Vol. 30, Iss 1, Pg 23-32.

Dishawa MT, Strong DM, Brandy DB (2002). Extending the Task- Technology Fit Model with Self-Efficacy Constructs. Eighth Americas Conference on Information Systems.

Dishawa MT, Strong DM (1999). Extending the technology acceptance model with task-technology fit constructs. Inform. Manag., 36(1):9-21.

Fishbein, M. and Ajzen, I. (1975) Belief, Attitude, Intention, and Behavior: An Introduction to Theory and Research. Reading, Mass: Addison-Wesley

Gefen, DE, Karahanna, Straub DW (2003). Trust and TAM in online shopping: An integrated model. MIS Quarterly., 27, (1): 51-90.

Grant G. and Chau D. (2006): Developing a generic framework for e-Government in Hunter and Tan (eds) Advanced Topics in Global Information Management, vol. 5, pp 72-101. Idea Group.

Goodhue, D.L. and Thompson, R.L. (1995). Task-Technology Fit and Individual Performance, MIS Quarterly (19:2), pp. 213-236.

Hanudin A. (2007). Internet Banking Adoption Among Young Intellectuals, JIBC, Vol. 12, No.3 [online] Available: http://www.arraydev. com/commerce/jibcl

Hussein, R., Mohamed, N., Ahlan, A. R., Mahmud, M., \& Aditiawarman, U. (2010). G2C adoption of e-government in Malaysia: Trust, perceived risk, and political self-efficacy. International Journal of Electronic Government Research, 6(3), 57-Ifinedo, P. (2007). Investigating the Antecedents of Continuance Intention of Course Management Systems Use among Estonian Undergraduates, International Journal of Information and Communication Technology Education, Vol. 3, No. 4, 76-92.

Jarvenpaa SL, Tractinsky N, Vitale M (2000). Consumer trust in an internet store. Inform. Technol. Manage., 1(12): 45-71.

Kamel, S., and Hassan, A. (2003). Assessing the Introduction of Electronic Banking in Egypt Using the Technology Acceptance Model, in Annals of Cases on Information Technology, M. Kosrow-Pour (Ed.), Idea Group Publishing, pp. 1- 25.

Klopping I. M. and McKinney E.I. (2004). Extending the Technology Acceptance Model and the Task-Technology Fit Model to Consumer E-Commerce, Information Technology, Learning, and Performance Journal, Vol. 22, №. 1.

Kollmann T. and Kayser I (2010), A Comprehensive Approach to Citizen Engagement in e-democracy. Proceedings of the 6th International Conference on e-government

Kumar, V., Mukerji, B., Butt, I. and Persaud, A. (2007) "Factors for Successful e-Government Adoption: a Conceptual Framework" The Electronic Journal of e-Government Volume 5 Issue 1, pp 63 - 76, available online at www.ejeg.com

Lai, C, S, A, and Pires, G. (2010) "Testing of a Model Evaluating e-Government Portal Acceptance and Satisfaction" The Electronic Journal Information Systems Evaluation Volume 13 Issue 1 2010, (pp35 - 46), available online at www.ejise.com

Layne, K. and Lee J. (2001). Developing Fully Functional E-Government: A Four-Stage Model. Government Information Quarterly 18(2): 
122-36.

LeBlanc, P., Mbarika, V., McCoy, S., \& Meso, P. (2004). "TeleDemocracy in developing countries: a focus on Sub-Saharan Africa". Proceedings of the 2004 Information Resource Management Association (IRMA 2004) International Conference, New Orleans, LA.

Lee D, Park J, Ahn, J (2001). On the explanation of factors affecting ecommerce adoption. Proceedings of the Twenty-Second International Conference in Information System. pp.109-120.

Lopez-Sisniega, C. (2009). "Barriers to Electronic Government use as Perceived by Citizens at the Municipal Level in Mexico". Proceedings of 5 th International Conference on e-government.

Macintosh, A. (2004). "Characterizing E-Participation in Policy-Making". Proceedings of the 37th Hawaii International Conference on System Sciences, Computer Society Press.

Olphert, W. and Damodaran, L. (2007). Citizen Participation and engagement in the Design of e-Government Services: The Missing Link in Effective ICT Design and Delivery, Journal of Association for Information Systems, Vol. 8, Issue 9, Article 4, pp. 491-507

OECD (3003): Promise and Problems of e-Democracy - Challenges of online Citizen Engagement

Paivarinta, T. and Øystein, S. (2006). Models of E-Democracy, Communications of the Association for Information Systems. Vol 17, Article 37

Pallant J. (2004). SPSS Survival Manual, Open University Press, McGraw-Hill London.

Pavlou PA (2003). Consumer Acceptance of Electronic Commerce: Integrating Trust and Risk with the Technology Acceptance. Int. J. Electron. Commun., 7:3.

Sahay, S., and Avgerou, C. (2002). "Introducing the Special Issue on Information and Communication Technologies in Developing Countries". The Information Society, 18(2), pp. 73-76.

Palvia, S. J. and Sharma, S. S. (2007). E-Government and E-Governance: Definitions/Domain Framework and Status around the World, Proceeding Int'l Conference on E-government. Hyderabad, India.

Sharma, N., and Patterson, P. 1999. The Impact of Communication Effectiveness and Service Quality on Relationship Commitment in Consumer, Professional Services, The Journal of Services Marketing (13:2), 1999, pp. 151- 170.

Steven Clift, The E-Democracy E-Book: Democracy is Online 2.0 (2000).

Stewart, K. (1999) "Transference as a Means of Building Trust in World Wide Web Sites," in Proceedings of the Twentieth International Conference on Information Systems, P. De and J. I. DeGross (eds.), Charlotte, NC.

Usoro A (2010). Task-Technology Fit and Technology Acceptance Models Applicability to e-Tourism. J. Econ. Dev. Manage. IT, Financ. Market., 2(1): 1-32.

Tassabehji, R. and Elliman, T. (2006) Generating Citizen Trust in e-Government Using a Trust Verification Agent: A Research Note. European and Mediterranean Conference on Information Systems (EMCIS), http://www.iseing.org/emcis/EMCIS2006/ Proceedings/Contributions/EGISE /eGISE4.pdf

Tolbert, Caroline, and Karen Mossberger. 2006. The Effects of E-Government on Trust and Confi dence in Government. Public Administration Review 66(3): 354-69.

Tzy-Wen T, Wen-Hai C (2005). The Role of Trust in Customer Online Shopping Behavior: Perspective of Technology Acceptance Model http://www.casos.cs.cmu.edu/events/conferences/2005/2005_proceedings/Tang.pdf

Venkatesh, V., Morris, M., Davis, G. and Davis, F. (2003) User Acceptance of Information Technology: Toward a Unified View. MIS Quarterly. 27(3): pp. 425-478.

Vatanasombut, B., Igbaria, M., Stylianou, A. C. and Rodgers, W. (2008). Information Systems continuance intention of web-based applications customers: The case of online banking. Information \& Management, 45 (7), 419-428.

Wang, Y., Wang, Y, Lin, H. \& Tang, T. (2003). Determinants of user acceptance of Internet banking: an empirical study, International Journal of Service Industry Management, Vol. 14, No. 5, 501-519.

Warkentin, M., Gefen, D., Pavlou, P. A., and Rose, Gregory M. (2002) Encouraging Citizen Adoption of e-Government by Building Trust. Electronic Markets, 12(3): p. 157-162. 